\title{
The Design, Synthesis, and Characterization of Resveratrol Derivatives Modified by Different $\gamma$-Aminobutyric Acid Esters
}

\author{
Bing Ren Tian $\mathbb{D}^{1},{ }^{1}$ Jia Yue Liu, ${ }^{1}$ Hu Rong Ge $\mathbb{D}^{2},{ }^{2}$ Zhi Zhong Wang $\mathbb{D}^{1},{ }^{1}$ \\ Shao Yun Huang, ${ }^{2}$ Yu Ying Wang, ${ }^{1}$ Qing Huang $\mathbb{D},{ }^{1}$ and Rui Xia Zhang $\mathbb{D}^{3}$ \\ ${ }^{1}$ School of Pharmacy, Ningxia Medical University, Yinchuan 750004, China \\ ${ }^{2}$ Department of Physical Education, Ningxia Medical University, Yinchuan 750004, China \\ ${ }^{3}$ Department of Pharmacy, The Third People's Hospital of Yinchuan, Yinchuan 750004, China \\ Correspondence should be addressed to Qing Huang; hq82@163.com and Rui Xia Zhang; zhangrxnx@163.com
}

Received 28 February 2019; Revised 23 April 2019; Accepted 7 May 2019; Published 16 June 2019

Academic Editor: Bartolo Gabriele

Copyright $(92019$ Bing Ren Tian et al. This is an open access article distributed under the Creative Commons Attribution License, which permits unrestricted use, distribution, and reproduction in any medium, provided the original work is properly cited.

A novel series of resveratrol modified by $\gamma$-aminobutyric acid esters were designed and synthesized. Then, the products were characterized by ${ }^{1} \mathrm{H}-\mathrm{NMR},{ }^{13} \mathrm{C}-\mathrm{NMR}$, and MS, and the melting point was determined. Molecular water solubility, polar surface area, and octanol-water partition were calculated, which correlated well with molecular transport through membranes and, therefore, enabled prediction of transport properties of drugs.

\section{Introduction}

Resveratrol (trans-3, 4', 5-trihydroxystilbene [Figure 1]) is a natural polyphenol $[1,2]$. It is widely distributed in edible plants, such as Polygonum cuspidatum and grapes [3, 4]. Modern pharmacological studies have indicated that resveratrol has beneficial effects on human health. For example, resveratrol can reduce blood fat levels [5], inhibit platelet activity [6], and protect against atherosclerosis and coronary heart disease [7]. Moreover, numerous studies have described the possible antifatigue function of resveratrol, and several researchers have paid increased attention to the physicochemical properties of resveratrol. Wu et al. found that resveratrol supplementation significantly increases exercise power. Therefore, they suggested that resveratrol may be applied as a potential food additive [8]. Hsu et al. found that the combination of resveratrol with kefir could reduce fatigue and improve exercise performance in mice when administered as a food supplement [9]. Resveratrol has been successfully combined with other protective chemical groups $[10,11]$. Mattarei et al. prepared amino acid carbamates as resveratrol prodrugs. They investigated the abilities and pharmacokinetic characteristics of these prodrugs and found that these products have appropriate stabilities [12].
Recently, prodrug was designed which had amino acids as promoieties [13]. Some properties of new prodrugs would be changed because of amino acid presence. Moreover, we hypothesized that incorporating suitable amino acids with promoieties that present antifatigue ability into prodrugs might have a positive effect. $\gamma$-Aminobutyric acid (GABA) (Figure 2), a four-carbon amino acid, is widely exist in numerous plants [14]. GABA plays an important role in the nervous system $[15,16]$. Supplementation with GABA or GABA-rich food for several weeks could exert a positive effect on exercise [17]. Although resveratrol and GABA can be employed as antifatigue additives, they cannot be combined together through chemical bonds. We selected GABA given its good research foundation.

The water solubility of liquids and solids is a crucial molecular property that influences the release, transport, and absorption of drugs in the body and is a key determinant of the environmental fate of agrochemicals and pollutants [18-21]. The octanol-water partition coefficient $\left(\log P_{\text {ow }}\right)$ and polar surface area (PSA) are widely used as general measures of lipophilicity and as parameters for predicting transcellular membrane transport properties in drug discovery research [22]. Numerous methods for the prediction of these properties have been developed [18, 22-24]. 


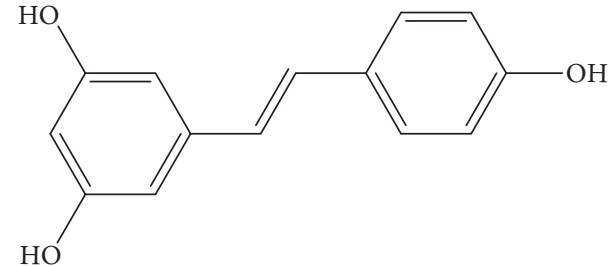

FIGURE 1: Structure of resveratrol.

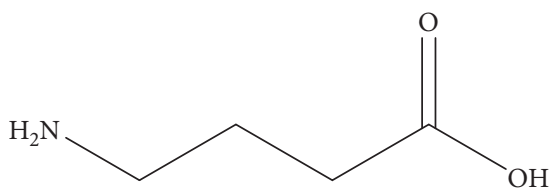

FIgURE 2: Structure of $\gamma$-aminobutyric acid.

In this study, we designed and synthesized novel resveratrol derivatives that had been modified with different GABA esters. Then, we applied ${ }^{1} \mathrm{H}-\mathrm{NMR},{ }^{13} \mathrm{C}-\mathrm{NMR}, \mathrm{MS}$, and melting point to characterize the compounds. In addition, we predicted and evaluated several qualities of the derivatives.

\section{Experiment}

2.1. Materials. Resveratrol was obtained from Chengdu Yuannuotiancheng Co., Ltd. (Sichuan, China). GABA, methanol, ethanol, $n$-propanol, thionyl chloride $\left(\mathrm{SOCl}_{2}\right)$, acetonitrile, bis(4-nitrophenyl) carbonate, and 4-dimethylaminopyridine (DMAP) were purchased from SigmaAldrich (Shanghai, China). All materials were used without further purification or modification.

\subsection{Methods}

2.2.1. General. Nuclear magnetic resonance (NMR, Bruker, $400 \mathrm{MHz}$, Germany) spectra were obtained using deuterated chloroform $\left(\mathrm{CDCl}_{3}\right)$, deuterated $\mathrm{H}_{2} \mathrm{O}\left(\mathrm{D}_{2} \mathrm{O}\right)$, or deuterated dimethyl sulfoxide $\left(\mathrm{d}_{6}-\mathrm{DMSO}\right)$ as a solvent. Peak positions and areas were analyzed by using MestReNova.

Melting points were measured with X-4 micromelting point tester.

(1) Polar Surface Area (PSA) Calculations. The PSA values of the investigated molecules were calculated by using ALOGPS 2.1 software (available at Virtual Computational Chemistry Laboratory, http://www.vcclab.org).

(2) Solubility Calculations. The solubility values of the investigated molecules were calculated by using ALOGPS 2.1 software (available at Virtual Computational Chemistry Laboratory, http://www.vcclab.org).

(3) Octanol-Water Partition ( $\left.\log P_{\text {ow }}\right)$ Calculations. The $\log P_{\text {ow }}$ values of the investigated molecules were calculated by using the Molinspiration Property Calculator (http:// www.molinspiration.com).

2.2.2. Synthesis Procedures. For an outline of the general strategy, refer to the Results and Discussion section.

(1) Methyl 4-Aminobutanoate (2a). Methanol (20 ml, $493.13 \mathrm{mmol}, 12.27$ equiv) was added to a reaction flask $(50 \mathrm{ml})$. Next, $\mathrm{SOCl}_{2}(2.81 \mathrm{ml}, 38.80 \mathrm{mmol}, 1$ equiv) was slowly added dropwise. Then, the mixture was stirred at $0^{\circ} \mathrm{C}$ for $1.5 \mathrm{~h}$. GABA ( $4 \mathrm{~g}, 38.80 \mathrm{mmol}, 1$ equiv) was added to the reaction system upon the completion of the first step of the reaction. The mixture was heated at $65^{\circ} \mathrm{C}$ under reflux for $1.5 \mathrm{~h}$. The reaction was monitored through TLC. The solvent was evaporated under reduced pressure, and the residue was purified through flash chromatography (eluent: $\mathrm{CH}_{2} \mathrm{Cl}_{2} /$ methanol, 1:1) to afford 1a $(3.97 \mathrm{~g}, 87 \%) . \mathrm{C}_{5} \mathrm{H}_{11} \mathrm{NO}_{2}$ (117.15) $[\mathrm{M}+\mathrm{H}]^{+}=118.2 .{ }^{1} \mathrm{H}$ NMR $\left(400 \mathrm{MHz}, \mathrm{CDCl}_{3}\right)$ $\delta=3.70\left(s, 3 \mathrm{H},-\mathrm{O}-\mathrm{CH}_{3}\right), 3.16\left(s, 2 \mathrm{H}, \mathrm{NH}_{2}-\mathrm{CH}_{2}-\right), 2.55(t$, $\left.J=6.6,2 \mathrm{H},-\mathrm{C}(=\mathrm{O})-\mathrm{CH}_{2}-\right), 2.15\left(m, J=5.5,2 \mathrm{H},-\mathrm{CH}_{2}-\mathrm{CH}_{2}-\right.$ $\left.\mathrm{CH}_{2}-\right) .{ }^{13} \mathrm{C}$ NMR $(101 \mathrm{MHz}, \mathrm{DMSO}) \delta=173.12,51.90,38.44$, $30.63,22.82$; melting point: $115-116^{\circ} \mathrm{C}$.

(2) Methyl 4-((4-nitrophenoxy)carbonyl)amino)butanoate (2b). First, 2a (0.96 g, $8.2 \mathrm{mmol}, 1$ equiv), DMAP (2.00 g, $16.4 \mathrm{mmol}, 2$ equiv), and acetonitrile $(15 \mathrm{ml})$ were added to a reaction flask $(50 \mathrm{ml})$. Next, bis(4-nitrophenyl) carbonate (2.74 g, $9.00 \mathrm{mmol}, 1.1$ equiv) solvent was added dropwise to the reaction flask with acetonitrile $(15 \mathrm{ml})$. The reaction was heated $\left(50^{\circ} \mathrm{C}\right)$ for $3 \mathrm{~h}$. The mixture was extracted three times with dichloromethane $(150 \mathrm{ml})$ and hydrochloric acid $(0.5 \mathrm{~mol} / \mathrm{L}, 100 \mathrm{ml})$ after the completion of the reaction. The organic layer was collected and then dried over anhydrous sodium sulfate. The solvent was evaporated under reduced pressure, and the residue was purified through flash chromatography (eluent: PE/EA, 3:2) to afford $2 \mathbf{b}(1.91 \mathrm{~g}$, 82.7\%). $\mathrm{C}_{12} \mathrm{H}_{14} \mathrm{~N}_{2} \mathrm{O}_{6}$ (282.25), $[\mathrm{M}-\mathrm{H}]^{-}=281.0 .{ }^{1} \mathrm{H}$ NMR $\left(400 \mathrm{MHz}, \mathrm{CDCl}_{3}\right) \delta=8.27(d, J=9.1,2 \mathrm{H}, \mathrm{Ar}-\mathrm{H}), 7.34(d$, $J=9.1,2 \mathrm{H}, \mathrm{Ar}-\mathrm{H}), 3.73\left(s, 3 \mathrm{H},-\mathrm{O}-\mathrm{CH}_{3}\right), 3.38(d, J=6.3,2 \mathrm{H}$, $\left.-\mathrm{NH}-\mathrm{CH}_{2}-\right), 2.47\left(t, J=7.1,2 \mathrm{H},-\mathrm{C}(=\mathrm{O})-\mathrm{CH}_{2^{-}}\right), 1.97(d d$, $\left.J=13.9,7.0,2 \mathrm{H},-\mathrm{CH}_{2}-\mathrm{CH}_{2}-\mathrm{CH}_{2}-\right) \cdot{ }^{13} \mathrm{C}$ NMR $(101 \mathrm{MHz}$, $\left.\mathrm{CDCl}_{3}\right) \delta=173.74,155.89,153.21,144.72,125.13,121.97$, $51.88,40.80,31.29,24.69$; melting point: $92-93^{\circ} \mathrm{C}$.

(3) Dimethyl 4,4'-((((5-(4-((4-methoxy-4-oxobutyl)carbamoyl) oxy)styryl)-1,3-phenylene)bis(oxy))bis(carbonyl))bis(azanediyl)) (E)-dibutyrate (2c). Resveratrol ( $0.25 \mathrm{~g}, 1.1 \mathrm{mmol}, 1$ equiv) and DMAP $(0.52 \mathrm{~g}, 4.2 \mathrm{mmol}$, 4 equiv) were added to a reaction flask $(50 \mathrm{ml})$. The mixture was stirred and dissolved with acetonitrile $(15 \mathrm{ml})$. Next, $2 \mathbf{b}$ ( $1.35 \mathrm{~g}, 4.8 \mathrm{mmol}, 4.5$ equiv) was dissolved and added to the above reaction system with acetonitrile $(15 \mathrm{ml})$. The mixture was then reacted under heating $\left(50^{\circ} \mathrm{C}\right)$ for $24 \mathrm{~h}$. The reaction was monitored through TLC. The solvent was evaporated under reduced pressure, and the residue was purified through flash chromatography (eluent: PE/EA, $1: 2)$ to afford $1 \mathrm{c}(0.56 \mathrm{~g}, 78 \%) . \mathrm{C}_{32} \mathrm{H}_{39} \mathrm{~N}_{3} \mathrm{O}_{12}(657.67)$, $[\mathrm{M}+\mathrm{H}]^{+}=658.8 .{ }^{1} \mathrm{H}$ NMR $(400 \mathrm{MHz}, \mathrm{DMSO}) \delta=6.77-7.90$ $(m, J=12.6,6.8,9 \mathrm{H}, \mathrm{Ar}-\mathrm{H}), 3.61\left(s, 9 \mathrm{H}, 3 \times-\mathrm{O}-\mathrm{CH}_{3}\right), 3.10(d d$, 
$\left.J=5.8,2.6,6 \mathrm{H}, 3 \times-\mathrm{NH}-\mathrm{CH}_{2}-\right), 2.39(d d, J=7.4,4.4,6 \mathrm{H}$, $\left.3 \times-\mathrm{C}(=\mathrm{O})-\mathrm{CH}_{2}-\right), 1.73\left(m, J=7.1,6 \mathrm{H}, 3 \times-\mathrm{CH}_{2}-\mathrm{CH}_{2}-\mathrm{CH}_{2}-\right)$. ${ }^{13} \mathrm{C}$ NMR (101 MHz, DMSO) $\delta=173.55,154.55,152.17$, $151.24,139.36,134.00,129.62,127.94,122.51,116.81,115.15$, $51.77,40.25,31.02,25.03$; melting point: $82-83^{\circ} \mathrm{C}$.

(4) Ethyl 4-Aminobutanoate (3a). Ethanol (20 ml, $342.96 \mathrm{mmol}$, 8.8 equiv) was added to the reaction flask $(50 \mathrm{ml})$. $\mathrm{SOCl}_{2}(2.81 \mathrm{ml}, 38.80 \mathrm{mmol}, 1$ equiv) was then slowly added dropwise. Next, the mixture was stirred at $0^{\circ} \mathrm{C}$ for $1.5 \mathrm{~h}$. GABA ( $4 \mathrm{~g}, 38.80 \mathrm{mmol}$, 1 equiv) was added to the reaction system upon the completion of the first step of the reaction. The mixture was heated $\left(65^{\circ} \mathrm{C}\right)$ under reflux for $1.5 \mathrm{~h}$. The reaction was monitored through TLC. The solvent was evaporated under reduced pressure, and the residue was purified through flash chromatography (eluent: $\mathrm{CH}_{2} \mathrm{Cl}_{2} /$ methanol, $1: 1$ ) to afford 3a (4.90 g, 98\%). $\mathrm{C}_{6} \mathrm{H}_{13} \mathrm{NO}_{2}(131.18),[\mathrm{M}+\mathrm{H}]^{+}=132.0 .{ }^{1} \mathrm{H}$ NMR $\left(400 \mathrm{MHz}, \mathrm{D}_{2} \mathrm{O}\right) \delta=4.07\left(q, J=7.1,2 \mathrm{H},-\mathrm{O}-\mathrm{CH}_{2}-\mathrm{CH}_{3}\right)$, $2.94\left(t, J=7.6,2 \mathrm{H}, \mathrm{NH}_{2}-\mathrm{CH}_{2}-\right), 2.41(t, J=7.3,2 \mathrm{H},-\mathrm{C}(=\mathrm{O})-$ $\left.\mathrm{CH}_{2}{ }^{-}\right), 1.93-1.80\left(m, 2 \mathrm{H},-\mathrm{CH}_{2}-\mathrm{CH}_{2}-\mathrm{CH}_{2}{ }^{-}\right), 1.15(t, J=7.2,3 \mathrm{H}$, $\left.-\mathrm{CH}_{2}-\mathrm{CH}_{3}\right) .{ }^{13} \mathrm{C}$ NMR $\left(101 \mathrm{MHz}, \mathrm{D}_{2} \mathrm{O}\right) \delta=175.14,61.90,38.73$, 30.82 , 22.02, 13.30; melting point: $81-82^{\circ} \mathrm{C}$.

(5) Ethyl 4-(((4-nitrophenoxy)carbonyl)amino)butanoate (3b). 3a ( $0.96 \mathrm{~g}, 8.2 \mathrm{mmol}$, 1 equiv), DMAP (2.00 g, $16.4 \mathrm{mmol}, 2$ equiv), and acetonitrile $(15 \mathrm{ml})$ were added to a reaction flask $(50 \mathrm{ml})$. Next, bis(4-nitrophenyl) carbonate (2.74 g, $9.00 \mathrm{mmol}, 1.1$ equiv) solvent was added dropwise to the reaction flask with acetonitrile $(15 \mathrm{ml})$, and the reaction was heated $\left(50^{\circ} \mathrm{C}\right)$ for $3 \mathrm{~h}$ after the reaction was completed. The mixture was extracted three times with dichloromethane $(150 \mathrm{ml})$ and hydrochloric acid $(0.5 \mathrm{~mol} / \mathrm{L}, 100 \mathrm{ml})$. The organic layer was collected and then dried over anhydrous sodium sulfate. The solvent was evaporated under reduced pressure, and the residue was purified through flash chromatography (eluent: PE/EA, 3:2) to afford $3 \mathbf{b}$ (1.91 g, 82.7\%). $\mathrm{C}_{13} \mathrm{H}_{10} \mathrm{~N}_{2} \mathrm{O}_{6}$ (296.28), $[\mathrm{M}+\mathrm{H}]^{+}=297.4 .{ }^{1} \mathrm{H} \mathrm{NMR}$ (400 MHz, DMSO) $\delta=8.27(d, J=9.2,2 \mathrm{H}, \mathrm{Ar}-\mathrm{H}), 7.41(d$, $J=9.2,2 \mathrm{H}, \mathrm{Ar}-\mathrm{H}), 4.07\left(q, J=7.1,2 \mathrm{H},-\mathrm{O}-\mathrm{CH}_{2}-\mathrm{CH}_{3}\right), 3.12$ $\left(d d, J=12.8,6.8,2 \mathrm{H},-\mathrm{NH}-\mathrm{CH}_{2}-\right), 2.37(t, J=7.4,2 \mathrm{H},-\mathrm{C}$ $\left.(=\mathrm{O})-\mathrm{CH}_{2}-\right), 1.74\left(p, J=7.2,2 \mathrm{H},-\mathrm{CH}_{2}-\mathrm{CH}_{2}-\mathrm{CH}_{2}-\right), 1.19(t$, $\left.J=7.1, \quad 3 \mathrm{H}, \quad-\mathrm{CH}_{2}-\mathrm{CH}_{3}\right) .{ }^{13} \mathrm{C} \mathrm{NMR}(101 \mathrm{MHz}, \quad \mathrm{DMSO})$ $\delta=172.99,156.67,153.59,144.54,125.59,122.92,60.28$, $40.31,31.21,24.92,14.56$; melting point: $77-78^{\circ} \mathrm{C}$.

(6) Diethyl 4,4'-(((5-(4-(((4-ethoxy-4-oxobutyl)carbamoyl)oxy) styryl)-1,3-phenylene)bis(oxy))bis(carbonyl))bis(azanediyl))(E)dibutyrate (3c). Resveratrol $(0.25 \mathrm{~g}, 1.1 \mathrm{mmol}, 1$ equiv) and DMAP ( $0.52 \mathrm{~g}, 4.2 \mathrm{mmol}, 4$ equiv) were added to the reaction flask $(50 \mathrm{ml})$. The mixture was stirred and dissolved with acetonitrile $(15 \mathrm{ml})$. Next, 2b $(1.48 \mathrm{~g}, 5.0 \mathrm{mmol}$, 4.5 equiv) was dissolved, added to the above reaction system with acetonitrile $(15 \mathrm{ml})$, and reacted under heating $\left(50^{\circ} \mathrm{C}\right)$ for $24 \mathrm{~h}$. The reaction was monitored through TLC. The solvent was evaporated under reduced pressure, and the residue was purified through flash chromatography (eluent: $\mathrm{PE} / \mathrm{EA}, 3: 1)$ to afford 3c $(0.54 \mathrm{~g}, 74 \%) . \mathrm{C}_{35} \mathrm{H}_{45} \mathrm{~N}_{3} \mathrm{O}_{12}$ (699.75), $[\mathrm{M}+\mathrm{H}]^{+}=700.4 .{ }^{1} \mathrm{H}$ NMR $(400 \mathrm{MHz}, \mathrm{DMSO})$ $\delta=7.86-7.12(m, 9 \mathrm{H}, \mathrm{Ar}-\mathrm{H}), 4.07\left(q, J=7.1,6 \mathrm{H}, 3 \times-\mathrm{O}-\mathrm{CH}_{2^{-}}\right.$
$\left.\left.\mathrm{CH}_{3}\right), 3.10\left(d, J=6.1,6 \mathrm{H}, 3 \times-\mathrm{NH}-\mathrm{CH}_{2}\right)^{-}\right), 2.37(t d, J=7.4$, $\left.2.8,6 \mathrm{H}, 3 \times-\mathrm{C}(=\mathrm{O})-\mathrm{CH}_{2^{-}}\right), 1.82-1.65\left(\mathrm{~m}, 6 \mathrm{H}, 3 \times-\mathrm{CH}_{2^{-}}\right.$ $\left.\mathrm{CH}_{2}-\mathrm{CH}_{2}-\right), 1.19\left(t, J=7.1,9 \mathrm{H}, 3 \times-\mathrm{CH}_{2}-\mathrm{CH}_{3}\right) .{ }^{13} \mathrm{C} \mathrm{NMR}$ (101 MHz, DMSO) $\delta=173.04,154.52,152.16,151.24,139.34$, $133.98,129.61,127.92,122.49,116.77,115.10,60.27,40.19$, $31.27,25.06,14.58$; melting point: $58-59^{\circ} \mathrm{C}$.

(7) Propyl 4-aminobutanoate (4a). n-Propanol (20 ml, $266.2 \mathrm{mmol}, 6.9$ equiv) was added to a reaction flask $(50 \mathrm{ml})$. Next, $\mathrm{SOCl}_{2}(2.81 \mathrm{ml}, 38.80 \mathrm{mmol}, 1$ equiv) was slowly added dropwise. Then, the mixture was stirred at $0^{\circ} \mathrm{C}$ for $1.5 \mathrm{~h}$. GABA ( $4 \mathrm{~g}, 38.80 \mathrm{mmol}, 1$ equiv) was added to the reaction system when the first step of the reaction was completed. The mixture was heated $\left(65^{\circ} \mathrm{C}\right)$ under reflux for $1.5 \mathrm{~h}$. The reaction was monitored through TLC. The solvent was evaporated under reduced pressure, and the residue was purified through flash chromatography (eluent: $\mathrm{CH}_{2} \mathrm{Cl}_{2} /$ methanol, $1: 1$ ) to afford $4 a(5.29 \mathrm{~g}, 94 \%) . \mathrm{C}_{7} \mathrm{H}_{15} \mathrm{NO}_{2}(145.20),[\mathrm{M}+\mathrm{H}]^{+}=146.2$. ${ }^{1} \mathrm{H}$ NMR $\left(400 \mathrm{MHz}, \mathrm{D}_{2} \mathrm{O}\right) \delta=3.99\left(t, J=6.7,2 \mathrm{H},-\mathrm{O}-\mathrm{CH}_{2^{-}}\right)$, $2.94\left(t, J=7.7,2 \mathrm{H}, \mathrm{NH}_{2}-\mathrm{CH}_{2^{-}}\right), 2.42(t, J=7.3,2 \mathrm{H},-\mathrm{C}(=\mathrm{O})$ $\left.\mathrm{CH}_{2-}\right), 1.94-1.81\left(m, 2 \mathrm{H},-\mathrm{CH}_{2}-\mathrm{CH}_{2}-\mathrm{CH}_{2}-\right), 1.55$ (dd, $J=14.2$, $\left.7.1,2 \mathrm{H},-\mathrm{CH}_{2}-\mathrm{CH}_{2}-\mathrm{CH}_{3}\right), 0.81\left(t, J=11.7,7.5,3 \mathrm{H},-\mathrm{CH}_{2^{-}}\right.$ $\left.\mathrm{CH}_{3}\right) .{ }^{13} \mathrm{C}$ NMR $\left(101 \mathrm{MHz}, \mathrm{D}_{2} \mathrm{O}\right) \delta=175.22,67.33,38.67$, 30.72 , 24.54, 21.25, 9.54; melting point: $104-105^{\circ} \mathrm{C}$.

(8) Propyl 4-(((4-nitrophenoxy)carbonyl)amino)butanoate (4b). 4a (0.96 g, $8.2 \mathrm{mmol}, 1$ equiv), DMAP (2.00 g, $16.4 \mathrm{mmol}$, 2 equiv), and acetonitrile (15 ml) were added to a reaction flask $(50 \mathrm{ml})$. Subsequently, bis(4-nitrophenyl) carbonate $(2.74 \mathrm{~g}$, $9.00 \mathrm{mmol}$, 1.1 equiv) solvent was added dropwise to the reaction flask with acetonitrile $(15 \mathrm{ml})$. The reaction was then heated $\left(50^{\circ} \mathrm{C}\right)$ for $3 \mathrm{~h}$. The mixture was extracted three times with dichloromethane $(150 \mathrm{ml})$ and hydrochloric acid $(0.5 \mathrm{~mol} / \mathrm{L}, 100 \mathrm{ml})$ after the reaction was completed. The organic layer was collected and then dried over anhydrous sodium sulfate. The solvent was evaporated under reduced pressure, and the residue was purified through flash chromatography (eluent: PE/EA, $3: 2$ ) to afford $\mathbf{4 b}$ (1.91 g, 82.7\%). $\mathrm{C}_{14} \mathrm{H}_{18} \mathrm{~N}_{2} \mathrm{O}_{6}$ (310.31), $[\mathrm{M}+\mathrm{H}]^{+}=311.4 .{ }^{1} \mathrm{H} \mathrm{NMR}(400 \mathrm{MHz}$, DMSO) $\delta=8.27(d, J=9.2,2 \mathrm{H}, \mathrm{Ar}-\mathrm{H}), 7.41(d, J=9.2,2 \mathrm{H}, \mathrm{Ar}-$ $\mathrm{H}), 3.98\left(t, J=6.7,2 \mathrm{H},-\mathrm{O}-\mathrm{CH}_{2}-\right), 3.12(d d, J=12.8,6.8,2 \mathrm{H}$, $\left.-\mathrm{NH}-\mathrm{CH}_{2}-\right), 2.38\left(t, J=7.4,2 \mathrm{H},-\mathrm{C}(=\mathrm{O})-\mathrm{CH}_{2^{-}}\right), 1.81-1.70(m$, $\left.2 \mathrm{H},-\mathrm{NH}-\mathrm{CH}_{2}-\mathrm{CH}_{2}-\mathrm{CH}_{2^{-}}\right), 1.64-1.54\left(m, 2 \mathrm{H}, \mathrm{CH}_{3}-\mathrm{CH}_{2}-\right)$, $0.89\left(t, J=7.4,3 \mathrm{H},-\mathrm{CH}_{2}-\mathrm{CH}_{3}\right) .{ }^{13} \mathrm{C} \mathrm{NMR}(101 \mathrm{MHz}, \mathrm{DMSO})$ $\delta=173.24,164.40,158.51,140.02,126.63,116.23,65.67,40.36$, $31.43,26.01,21.98,10.71$; melting point: $43-44^{\circ} \mathrm{C}$.

(9) Dipropyl 4,4'-(((5-(4-((4-oxo-4-propoxybutyl)carbamoyl) oxy)styryl)-1,3-phenylene)bis(oxy))bis(carbonyl))bis(azanediyl)) (E)-dibutyrate ( $4 c)$. Resveratrol ( $0.25 \mathrm{~g}, 1.1 \mathrm{mmol}, 1$ equiv) and DMAP (0.52 g, $4.2 \mathrm{mmol}$, 4 equiv) were added to the reaction flask $(50 \mathrm{ml})$. The mixture was stirred and dissolved with acetonitrile $(15 \mathrm{ml})$. Subsequently, 4 b $(1.54 \mathrm{~g}, 5.0 \mathrm{mmol}$, 4.5 equiv) was dissolved, added to the above reaction system with acetonitrile $(15 \mathrm{ml})$, and reacted under heating $\left(50^{\circ} \mathrm{C}\right)$ for $24 \mathrm{~h}$. The reaction was monitored through TLC. The solvent was evaporated under reduced pressure, and the residue was purified through flash chromatography (eluent: PE/EA, $1: 1)$ to afford $4 \mathrm{c}(0.69 \mathrm{~g}, 85 \%) . \mathrm{C}_{38} \mathrm{H}_{51} \mathrm{~N}_{3} \mathrm{O}_{12}$ (741.84), 


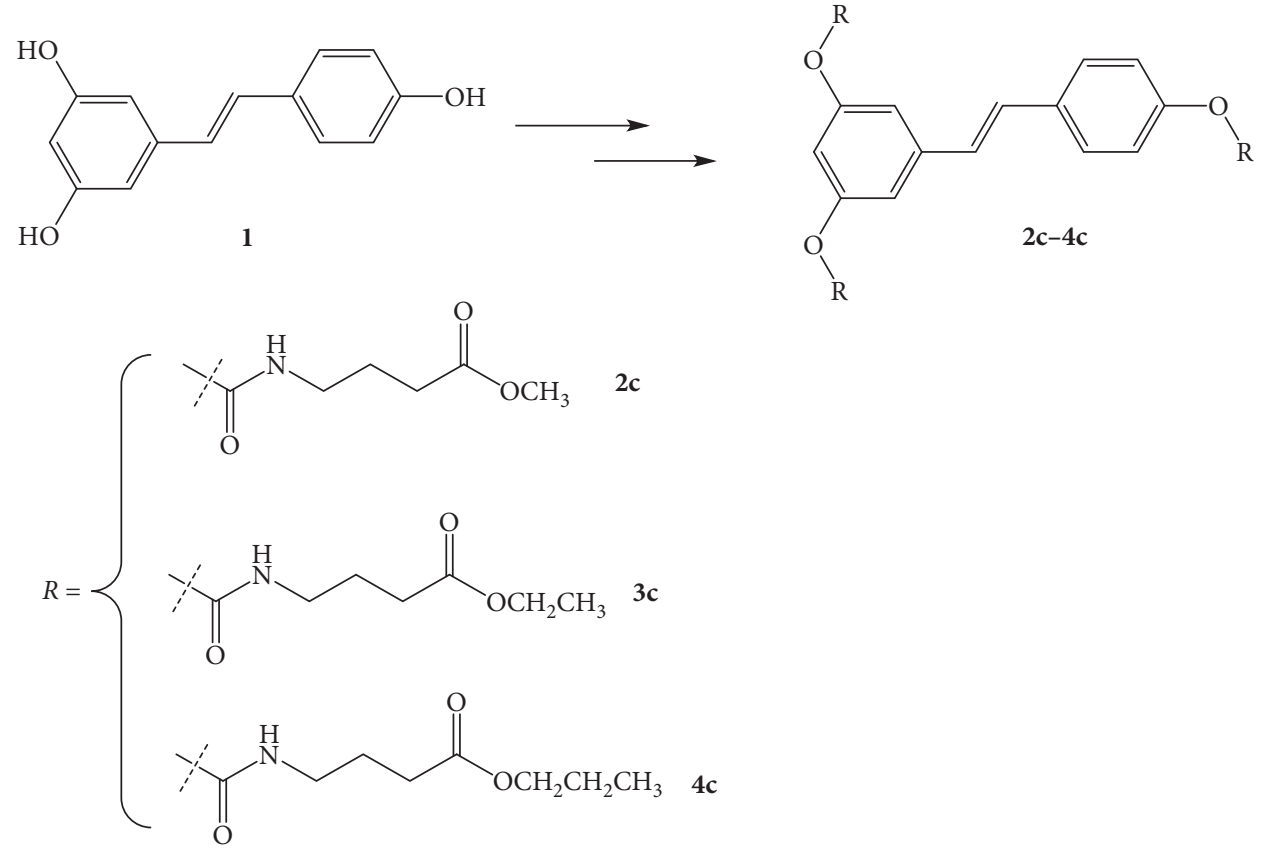

Scheme 1: Molecular structure of resveratrol and its carbonate derivatives.

$[\mathrm{M}+\mathrm{H}]^{+}=742.5 .{ }^{1} \mathrm{H}$ NMR $(400 \mathrm{MHz}, \mathrm{DMSO}) \delta=8.29-6.70$ $(m, 9 \mathrm{H}), 3.99\left(t, J=6.6,6 \mathrm{H}, 3 \times \mathrm{CH}_{3}-\mathrm{CH}_{2}-\mathrm{CH}_{2}-\mathrm{O}-\right), 3.10$ $\left(d, J=3.2,6 \mathrm{H}, 3 \times-\mathrm{NH}-\mathrm{CH}_{2^{-}}\right), 2.38(t d, J=7.4,2.8,6 \mathrm{H}$, $\left.3 \times-\mathrm{C}(=\mathrm{O})-\mathrm{CH}_{2^{-}}\right), 1.74\left(t, J=8.6,6 \mathrm{H}, 3 \times-\mathrm{NH}-\mathrm{CH}_{2}-\mathrm{CH}_{2^{-}}\right)$, $1.59\left(d d, J=14.2,6.9,6 \mathrm{H}, 3 \times \mathrm{CH}_{3}-\mathrm{CH}_{2}-\right), 0.89(t, J=7.4,9 \mathrm{H}$, $\left.3 \times \mathrm{CH}_{3}-\mathrm{CH}_{2}-\right) .{ }^{13} \mathrm{C} \mathrm{NMR}(101 \mathrm{MHz}, \mathrm{DMSO}) \delta=173.10$, $154.52,152.15,151.23,139.34,133.98,129.60,127.91,122.49$, $116.78,116.25,65.76,40.26,31.25,25.09,22.00,10.74$; melting point: $65-66^{\circ} \mathrm{C}$.

\section{Results and Discussion}

3.1. Synthesis. Resveratrol was modified by various GABA esters to form the corresponding analogues $\mathbf{2 c - 4 c}$, as depicted in Scheme 1. Resveratrol and GABA are beneficial compounds that individually present several shortcomings [25]. Therefore, linking resveratrol and GABA with a chemical bond may obtain the novel derivatives with properties that are different from the properties of the individual parent molecule.

GABA can be connected through two methods because its structure contains carboxyl and amino groups. Connecting resveratrol to GABA through the amino bonds of amino acids would have a positive effect on the afforded prodrugs [26]. Hence, we selected this method to connect GABA with resveratrol (Scheme 2).

$N$-Monosubstituted carbamate esters are usually synthesized through two steps: first, the desired primary amine is reacted with a phosgene or its equivalent to give a reactive isocyanate derivative; then, the intermediate is coupled with the phenolic functional group [12, 27]. These procedures, however, provide low yields of the desired trisubstituted resveratrol derivatives likely because the high reactivity of the isocyanate group promotes the polymerization side reaction that entrains the stilbene $\mathrm{C}-\mathrm{C}$ double bond [28].
The final products were obtained with good yields through this route. In this study, we first protected carboxyl to obtain $2 \mathbf{a}-\mathbf{4 a}$. Then, we optimized and synthesized the 4 nitrophenyl carbamate intermediates $\mathbf{2} \mathbf{b}-\mathbf{4 b}$. We next reacted resveratrol with the isolated intermediates to acquire the transesterification products. Good to excellent yields of the final conjugates $\mathbf{2} \mathbf{c}-\mathbf{4} \mathbf{c}$ were obtained under mild conditions.

3.2. Prediction of $\log P_{\text {ow }}$, Solubility, and PSA. The $\log P_{\text {ow }}$ values, water solubility, and the polar surface area (PSA) values of all novel synthesized compounds were estimated (Table 1).

Molecular PSA is a highly useful indicator for predicting drug transport properties. PSA is the sum of the surfaces of polar atoms in a molecule. This parameter is highly correlated with human intestinal absorption, blood-brain barrier permeability, and Caco-2 permeability through a singlelayer film [22].

However, the classical PSA calculation method is time consuming because it requires the generation and surface determination of a reasonable three-dimensional molecular geometry. In addition, specialized software is needed to generate three-dimensional molecular structures and to determine surfaces.

A virtual library that consists of hundreds of thousands or even millions of molecules is needed to enable rapid bioavailability screening in the current era of highthroughput screening and combinatorial chemistry-driven drug development. Nowadays, this process is based on the summation of the surface contributions of polar fragments (atoms are also affected by their environment). We determined fragment contributions by fitting drugs from 34,810 World Drug Index through single-conformation 3D PSA least-square methods. Three-dimensional classical PSA 
<smiles>CCNCCCC(=O)OC</smiles><smiles>[R]OC(=O)CCCNC(=O)Oc1ccc([N+](=O)[O-])cc1</smiles>

$2 b-4 b$

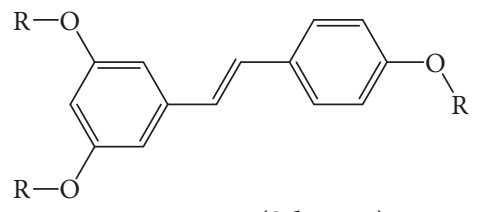

$$
X=-\mathrm{CH}_{3} \text { or }-\mathrm{CH}_{2} \mathrm{CH}_{3} \text { or }-\mathrm{CH}_{2} \mathrm{CH}_{2} \mathrm{CH}_{3}
$$

Scheme 2: Synthesis of derivatives $2 \mathrm{c}-4 \mathrm{c}$. Reagents and conditions: (a) (1) $\mathrm{SOCl}_{2}$, methanol/ethanol $/ n$-propanol, $0^{\circ} \mathrm{C}, 1 \mathrm{~h}$; (2) $65^{\circ} \mathrm{C}, 1.5 \mathrm{~h}$; (b) bis(4-nitrophenyl) carbonate, DMAP, $\mathrm{ACN}, 50^{\circ} \mathrm{C}, 3 \mathrm{~h}$; (c) resveratrol, DMAP, $50^{\circ} \mathrm{C}, 24 \mathrm{~h}$.

TABLe 1: $\log P_{\text {ow }}$, water solubility, and topological PSA values of resveratrol and corresponding derivatives.

\begin{tabular}{lccc}
\hline Compound & $\log P_{\text {ow }}$ & PSA $\left(\AA^{2}\right)$ & Solubility $(\mathrm{g} / \mathrm{L})$ \\
\hline Resveratrol & 2.57 & 60.68 & 0.03 \\
GABA & -2.99 & 63.32 & 1.73 \\
2a & -1.07 & 52.33 & 0.49 \\
2b & 1.44 & 110.46 & 0.03 \\
2c & 3.22 & 193.91 & 0.0033 \\
3a & -0.46 & 52.33 & 0.66 \\
3b & 1.86 & 110.46 & 0.02 \\
3c & 4.36 & 193.91 & 0.0025 \\
4a & 0.02 & 52.33 & 1.03 \\
4b & 2.23 & 110.46 & 0.01 \\
4c & 5.03 & 193.19 & 0.0018 \\
\hline
\end{tabular}

results for the topological PSA were virtually of the same quality, and the calculation speed was accelerated by 2 to 3 orders of magnitude [22]. The prediction results indicate that the final products $(\mathbf{2 c}-\mathbf{4 c})$ would have poor absorption (PSA $\geq 140 \AA^{2}$ ) [29].

The ability to penetrate cell membranes is related not only to PSA, but also to water solubility and octanol-water partitioning. $\log P_{\text {ow }}$ is used as an indicator of molecular hydrophobicity in QSAR studies and rational drug design. Hydrophobicity affects drug absorption, bioavailability, metabolism, and toxicity and hydrophobic drug-receptor interactions. $\log P_{\text {ow }}$ has become also a key parameter in studies on the environmental fate of chemicals. In addition, we used a database to calculate the water solubility of these products. Our results indicate that some properties of the derivatives have changed. Specifically, solubility decreased and $\log P_{\text {ow }}$ increased when the number of hydrophobic groups increased.

\section{Conclusion}

A series of resveratrol derivatives that had been modified with different GABA esters was successfully synthesized. The $\log P_{\text {ow }}$, water solubility, and topological PSA values of the derivatives were predicted by using software. Prediction results indicate that the properties of the derivatives were different from those of resveratrol. Finally, the melting point of the derivatives products was analyzed. The conjugates will be subjected to further formulation studies and biological evaluation on the basis of the results obtained in the present work.

\section{Data Availability}

The NMR and predicted data used to support the findings of this study are included within the article.

\section{Conflicts of Interest}

The authors declare no conflicts of interest.

\section{Authors' Contributions}

Bing Ren Tian and Jia Yue Liu have contributed equally to this work and are joint first authors.

\section{Acknowledgments}

This research was funded by the Higher Education Institution of Ningxia (No. NGY2016116) and Ningxia Medical University (No. XZ2015006). The APC was funded by Ningxia Medical University.

\section{References}

[1] B. D. Gehm, J. M. McAndrews, P.-Y. Chien, and J. L. Jameson, "Resveratrol, a polyphenolic compound found in grapes and wine, is an agonist for the estrogen receptor," Proceedings of the National Academy of Sciences, vol. 94, no. 25, pp. 14138-14143, 1997.

[2] J. Martinez and J. J. Moreno, "Effect of resveratrol, a natural polyphenolic compound, on reactive oxygen species and prostaglandin production," Biochemical Pharmacology, vol. 59, no. 7, pp. 865-870, 2000.

[3] J. Burns, T. Yokota, H. Ashihara, M. E. J. Lean, and A. Crozier, "Plant foods and herbal sources of resveratrol," Journal of Agricultural and Food Chemistry, vol. 50, no. 11, pp. 33373340, 2002.

[4] P. Jeandet, R. Bessis, M. Sbaghi, and P. Meunier, "Production of the phytoalexin resveratrol by grapes as a response to 
Botrytis attack under natural conditions," Journal of Phytopathology, vol. 143, no. 3, pp. 135-139, 1995.

[5] L. Rivera, R. Morón, A. Zarzuelo, and M. Galisteo, "Longterm resveratrol administration reduces metabolic disturbances and lowers blood pressure in obese Zucker rats," Biochemical Pharmacology, vol. 77, no. 6, pp. 1053-1063, 2009.

[6] L. Frémont, "Biological effects of resveratrol," Life Sciences, vol. 66, no. 8, pp. 663-673, 2000.

[7] C. R. Pace-Asciak, S. Hahn, E. P. Diamandis, G. Soleas, and D. M. Goldberg, "The red wine phenolics trans-resveratrol and quercetin block human platelet aggregation and eicosanoid synthesis: implications for protection against coronary heart disease," Clinica Chimica Acta, vol. 235, no. 2, pp. 207-219, 1995.

[8] R.-E. Wu, W.-C. Huang, C.-C. Liao, Y.-K. Chang, N.-W. Kan, and C.-C. Huang, "Resveratrol protects against physical fatigue and improves exercise performance in mice," Molecules, vol. 18, no. 4, pp. 4689-4702, 2013.

[9] Y.-J. Hsu, W.-C. Huang, J.-S. Lin et al., "Kefir supplementation modifies gut microbiota composition, reduces physical fatigue, and improves exercise performance in mice," $\mathrm{Nu}$ trients, vol. 10, no. 7, p. 862, 2018.

[10] A. Mattarei, M. Carraro, M. Azzolini, C. Paradisi, M. Zoratti, and L. Biasutto, "New water-soluble carbamate ester derivatives of resveratrol," Molecules, vol. 19, no. 10, pp. 15900-15917, 2014.

[11] Y. J. Ng, H. A. Benson, D. H. Brown, and Y. Chen, "Synthesis and characterization of novel copolymeric resveratrol conjugates," Journal of Chemistry, vol. 2015, Article ID 245625, 6 pages, 2015.

[12] A. Mattarei, M. Azzolini, M. La Spina, M. Zoratti, C. Paradisi, and L. Biasutto, "Amino acid carbamates as prodrugs of resveratrol," Scientific Reports, vol. 5, no. 1, p. 15216, 2015.

[13] B. S. Vig, K. M. Huttunen, K. Laine, and J. Rautio, "Amino acids as promoieties in prodrug design and development," Advanced Drug Delivery Reviews, vol. 65, no. 10, pp. 13701385, 2013.

[14] N. Bouché and H. Fromm, "GABA in plants: just a metabolite?," Trends in Plant Science, vol. 9, no. 3, pp. 110-115, 2004.

[15] J. S. Kim, I. J. Bak, R. Hassler, and Y. Okada, "Role of $\gamma$-aminobutyric acid (GABA) in the extrapyramidal motor system," Experimental Brain Research, vol. 14, no. 1, p. 95, 1971.

[16] S. J. Enna and S. H. Snyder, "Properties of $\gamma$-aminobutyric acid (GABA) receptor binding in rat brain synaptic membrane fractions," Brain Research, vol. 100, no. 1, pp. 81-97, 1975.

[17] F. Chaouloff, G. A. Kennett, B. Serrurrier, D. Merino, and G. Curzon, "Amino acid analysis demonstrates that increased plasma free tryptophan causes the increase of brain tryptophan during exercise in the rat," Journal of Neurochemistry, vol. 46, no. 5, pp. 1647-1650, 1986.

[18] W. L. Jorgensen and E. M. Duffy, "Prediction of drug solubility from structure," Advanced Drug Delivery Reviews, vol. 54, no. 3, pp. 355-366, 2002.

[19] M. H. Abraham and J. Le, "The correlation and prediction of the solubility of compounds in water using an amended solvation energy relationship," Journal of Pharmaceutical Sciences, vol. 88, no. 9, pp. 868-880, 1999.

[20] M. B. Oliveira, F. R. Varanda, I. M. Marrucho, A. J. Queimada, and J. A. P. Coutinho, "Prediction of water solubility in biodiesel with the CPA equation of state," Industrial \&
Engineering Chemistry Research, vol. 47, no. 12, pp. 42784285, 2008.

[21] A. R. Katritzky, Y. Wang, S. Sild, T. Tamm, and M. Karelson, "QSPR studies on vapor pressure, aqueous solubility, and the prediction of water-air partition coefficients," Journal of Chemical Information and Computer Sciences, vol. 38, no. 4, pp. 720-725, 1998.

[22] P. Ertl, B. Rohde, and P. Selzer, "Fast calculation of molecular polar surface area as a sum of fragment-based contributions and its application to the prediction of drug transport properties," Journal of Medicinal Chemistry, vol. 43, no. 20, pp. 3714-3717, 2000.

[23] G. Klopman and H. Zhu, "Recent methodologies for the estimation of $\mathrm{N}$-octanol/water partition coefficients and their use in the prediction of membrane transport properties of drugs," Mini-Reviews in Medicinal Chemistry, vol. 5, no. 2, pp. 127-133, 2005

[24] T. Cheng, Y. Zhao, X. Li et al., "Computation of octanolwater partition coefficients by guiding an additive model with knowledge," Journal of Chemical Information and Modeling, vol. 47, no. 6, pp. 2140-2148, 2007.

[25] J. J. Johnson, M. Nihal, I. A. Siddiqui et al., "Enhancing the bioavailability of resveratrol by combining it with piperine," Molecular Nutrition \& Food Research, vol. 55, no. 8, pp. 1169-1176, 2011.

[26] T. Szekeres, M. Fritzer-Szekeres, P. Saiko, and W. Jäger, "Resveratrol and resveratrol analogues-structure-activity relationship," Pharmaceutical Research, vol. 27, no. 6, pp. 1042-1048, 2010.

[27] X. Wu, L. Cheng, D. Xiang, and Y. Wei, "Syntheses of carbamate derivatives of quercetin by reaction with amino acid ester isocyanates," Letters in Organic Chemistry, vol. 2, no. 6, pp. 535-538, 2005.

[28] A. Mattarei, M. Azzolini, M. Zoratti, L. Biasutto, and C. Paradisi, "N-monosubstituted methoxy-oligo(ethylene glycol) carbamate ester prodrugs of resveratrol," Molecules, vol. 20, no. 9, pp. 16085-16102, 2015.

[29] D. E. Clark, "Rapid calculation of polar molecular surface area and its application to the prediction of transport phenomena 1. Prediction of intestinal absorption," Journal of Pharmaceutical Sciences, vol. 88, no. 8, pp. 807-814, 1999. 

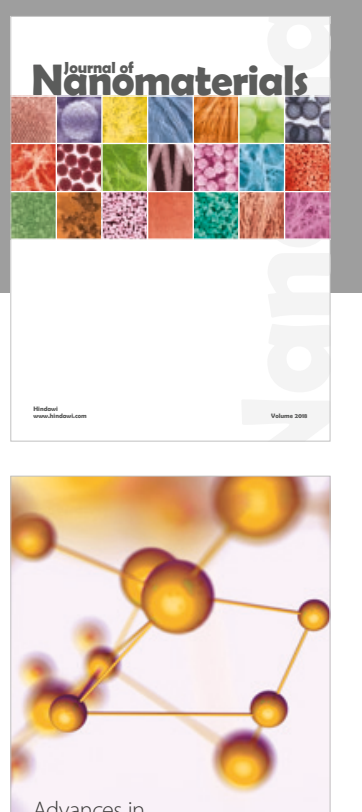

Physical Chemistry
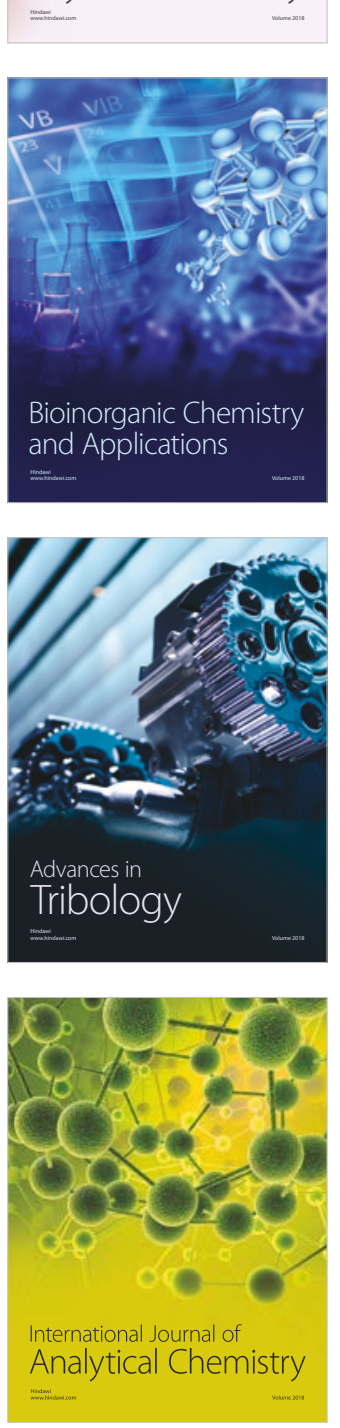

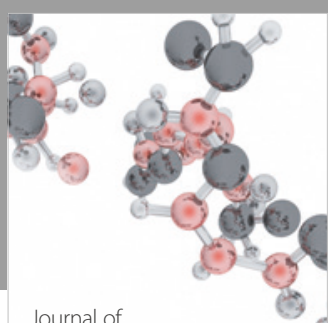

Analytical Methods

in Chemistry

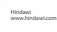

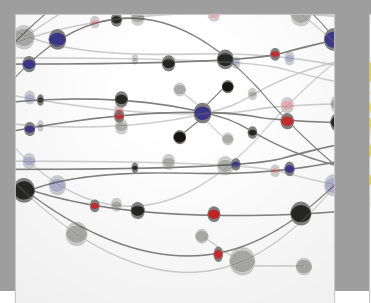

The Scientific World Journal

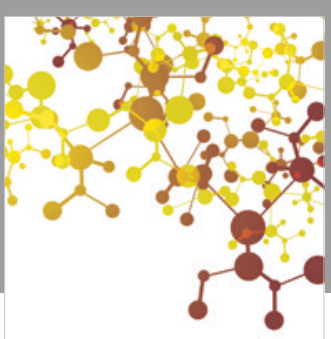

Journal of

Applied Chemistry
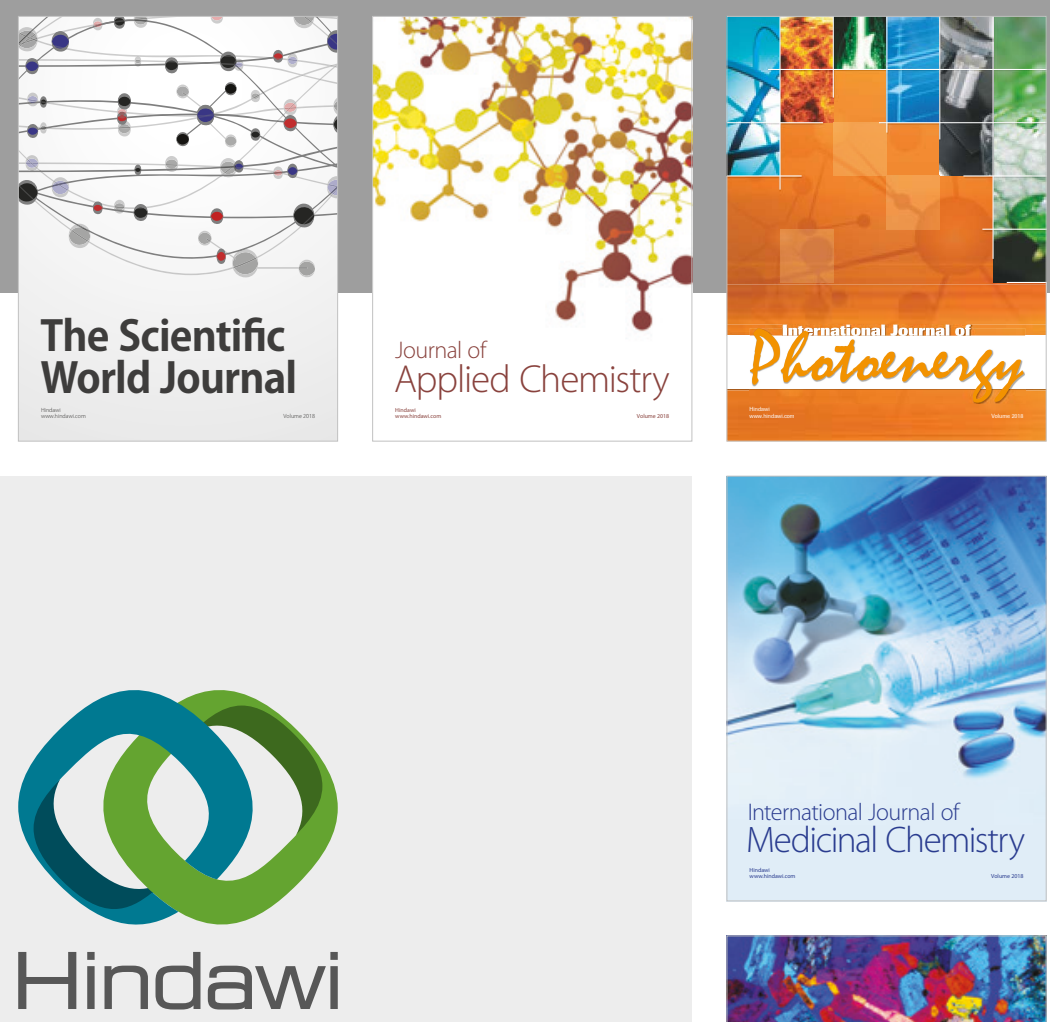

Submit your manuscripts at

www.hindawi.com
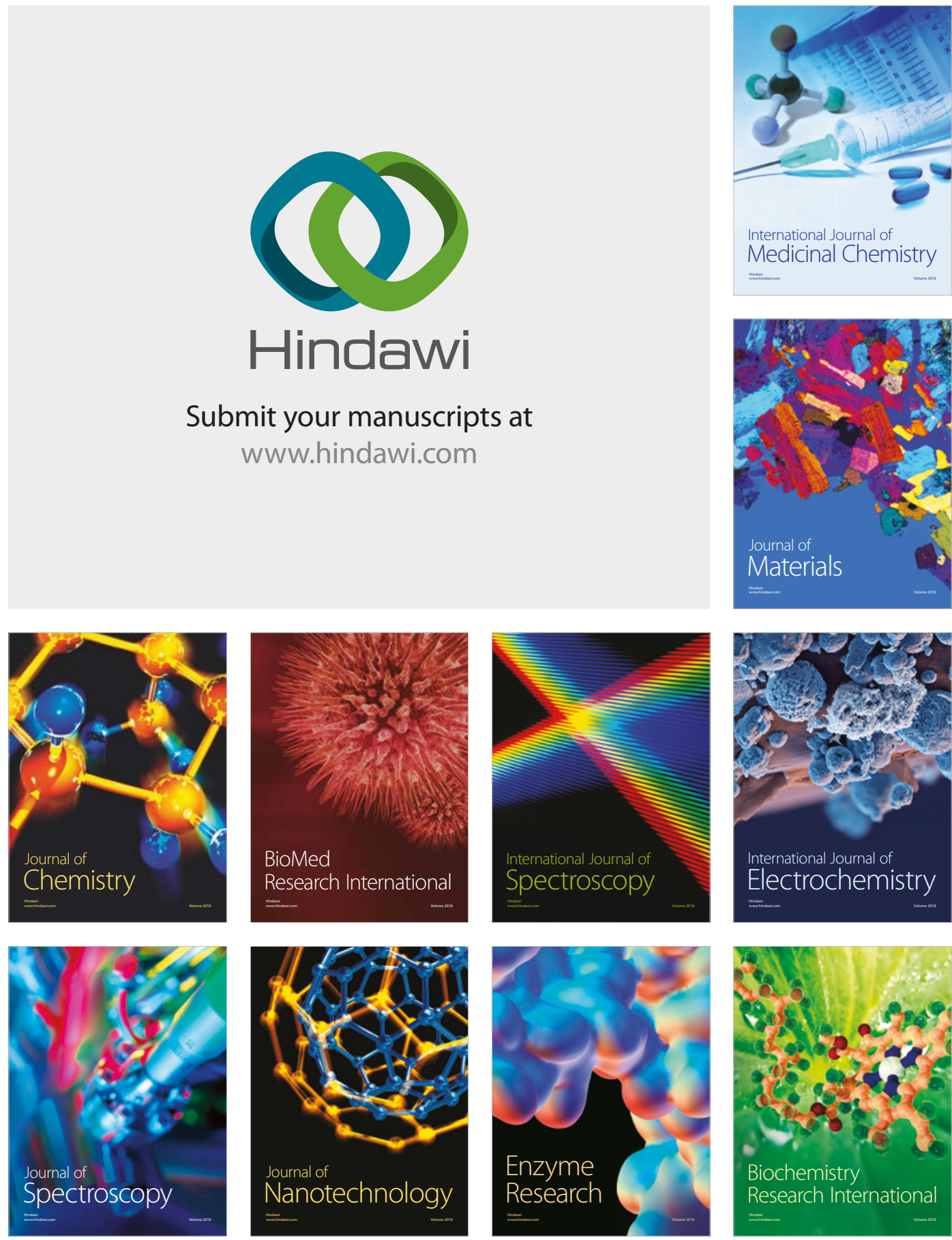
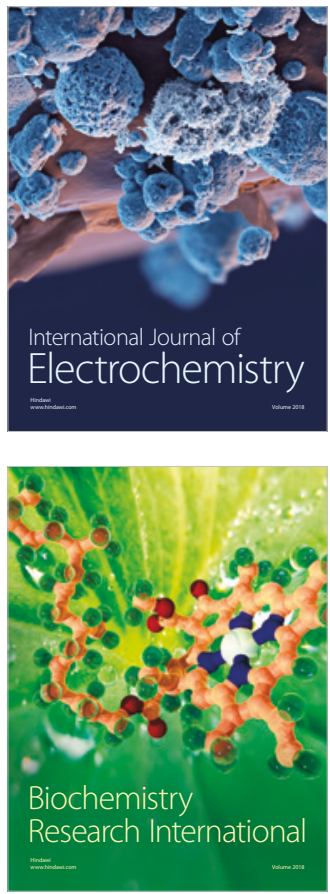